\title{
Catatan baru hama penting, Frankliniella intonsa (Trybom) (Thysanoptera: Thripidae) pada tanaman stroberi di Desa Alamendah, Kecamatan Rancabali Kabupaten Bandung, Jawa Barat
}

\author{
Frankliniella intonsa (Trybom) (Thysanoptera: Thripidae), a new \\ potential pest, on strawberry in Alamendah Village-Rancabali District, \\ Bandung Regency, West Java
}

Ciptadi Achmad Yusup, Dewi Sartiami*

Departemen Proteksi Tanaman, Fakutas Pertanian, Institut Pertanian Bogor

Jalan Kamper Kampus IPB Darmaga, Bogor 16680

(diterima Januari 2013, disetujui Oktober 2013)

\begin{abstract}
ABSTRAK
Stroberi termasuk tanaman buah baru yang masuk ke Indonesia, stroberi dengan cepat berkembang karena permintaan akan buah ini terus meningkat. Trips merupakan salah satu hama yang menyerang tanaman stroberi dan dapat mengurangi kualitas serta kuantitas produksi stroberi. Penelitian dilakukan di Desa Alamendah, Kecamatan Rancabali, Kabupaten Bandung dari bulan Maret sampai Agustus 2012. Trips yang menyerang tanaman stroberi di Desa Alamendah didominasi oleh Frankliniella intonsa (Trybom). Trips lain yang ditemukan pada tanaman di sekitar tanaman stroberi, yaitu Thrips palmi dan Microcephalothrips abdominalis. Kedua trips ini ditemukan pada tanaman tomat, kentang, bawang daun, blackberry, gulma Amaranthus sp. dan Ageratum haustonianum. Seluruh stadia pertumbuhan $F$. intonsa berada pada bunga stroberi dengan kerapatan populasi berkisar dari 1,8 sampai 2,3 individu imago/bunga. Luas serangan $F$. intonsa di lahan stroberi berkisar antara $68,4 \%$ sampai $82,2 \%$. Berdasarkan uji kemampuan $F$. intonsa menyerang tanaman stroberi, menunjukkan bahwa $43,3 \%$ buah sampel yang dipanen mengalami malformasi pada bagian ujung buah. Dengan demikian $F$. intonsa berpotensi menjadi hama penting tanaman stroberi.
\end{abstract}

Kata kunci: Thysanoptera, hama tanaman, Fragaria spp., gejala serangan

\begin{abstract}
Strawberry is a new crop in Indonesia, and it has been developed because of its high demands. Thrips is one of the strawberry pest that can reduce quality and quantity strawberry productions. The research was conducted in Alamendah-Rancabali Village, Bandung District from March to August 2012. Thrips species that attack strawberry in Alamendah Village dominated by Frankliniella intonsa (Trybom). Other thrips that were found on plants surround strawberry field is Thrips palmi and Microcephalothrips abdominalis. Both of these thrips are found on tomatoes, potatoes, leek, blackberries, weeds (Amaranthus sp. and Ageratum haustonianum). The complete stadia of $F$. intonsa were found on strawberry flowers. Population densities in the field were found to be between 1.8 to 2.3 individual/flower. Around $68.4 \%-82.2 \%$ of the fields are are infested with $F$. intonsa. Based on
\end{abstract}

\footnotetext{
*Penulis korespondensi: Dewi Sartiami. Departemen Proteksi Tanaman, Fakutas Pertanian, Institut Pertanian Bogor, 
test of $F$. intonsa attack ability on strawberry plant, the result shows $43 \%$ of fruit that harvested is malformed on tips of fruits. Therefore, $F$. intonsa is potential to become a important pest of strawberry plant.

Key words: Thysanoptera, Fragaria spp., plant pest, symptoms

\section{PENDAHULUAN}

Stroberi (Fragaria sp.) merupakan tanaman buah yang sudah banyak dibudidayakan masyarakat dunia termasuk Indonesia. Buah ini dapat dikonsumsi sebagai buah segar atau digunakan sebagai bahan baku produk makanan dan minuman lainnya. Dalam proses budi daya stroberi, ditemui banyak masalah disebabkan oleh gangguan organisme pengganggu tanaman. Masalah hama yang menyerang tanaman stroberi antara lain adalah ulat grayak, slug, kumbang putih, siput, kutu daun, penggerek buah, dan uret (Balijestro 2014)

Salah satu hama yang menyerang tanaman stroberi adalah trips. Trips menjadi hama utama yang menyerang stroberi di negara subtropis seperti Spanyol dan beberapa bagian Amerika Serikat. Akibat serangan trips ini kualitas produksi buah stroberi menurun dan diikuti oleh berkurangnya pendapatan petani stroberi (Parker et al. 2004). Trips yang menyerang stroberi di negara Spanyol dan Brazil adalah Frankliniella occidentalis (Pergande) (Thysanoptera: Thripidae). Serangan trips ini dapat menyebabkan buah menjadi kusam atau kecokelatan, kecil, dan lusuh karena aktivitas makan trips selama bunga mekar dan saat pembentukan buah (Zamora \& Mari 2003). Zamora \& Mari (2003) juga menyebutkan bahwa trips dapat mengakibatkan biji stroberi menghitam dan perkembangan buah yang tidak merata.

Di Indonesia trips belum dilaporkan sebagai hama pada stroberi sehingga data mengenai gejala kerusakan yang ditimbulkannya belum tersedia. Zamora \& Mari (2003) menyebutkan bahwa keberadaan trips pada tanaman stroberi sering diabaikan karena ukurannya yang relatif kecil dan trips lebih memilih menyerang bagian yang tertutupi seperti bagian di bawah kelopak bunga dan daerah cekungan sekitar biji stroberi. Serangan trips tidak terlalu memengaruhi kuantitas produksi buah stroberi, namun dapat menurunkan kualitas buah stroberi sehingga tidak memenuhi kriteria untuk dipasarkan di pasar swalayan yang memiliki nilai jual yang lebih tinggi.
Pengumpulan informasi dasar tentang biologi $F$. intonsa pada tanaman stroberi di Indonesia penting untuk dilakukan. Hama ini berpotensi menjadi hama penting pada komoditas stroberi di Indonesia. Informasi dasar mengenai biologi F. intonsa dapat digunakan sebagai acuan bagi penelitian lanjut tentang trips pada tanaman stroberi dan sebagai informasi bagi bidang taksonomi serangga Indonesia. Menurut De Kogel et al. (1999), ukuran tubuh berpengaruh terhadap kapasitas reproduktif trips $F$. occidentalis. Semakin panjang ukuran tubuh trips tersebut, maka tingkat reproduksinya akan semakin berkurang.

Kecamatan Rancabali merupakan salah satu sentra produksi stroberi di Indonesia. Kondisi iklim dan ketinggian tempat yang mendukung, ditambah terdapatnya banyak obyek wisata alam seperti Kawah Putih dan Situ Patenggang sangat mendukung untuk pengembangan usaha agrowisata buah stroberi.

Permintaan stroberi di Ciwidey, Kabupaten Bandung, selama tahun 2005 mencapai 700-1000 $\mathrm{kg}$ /hari, namun petani hanya mampu memenuhi kebutuhan stroberi sebanyak $700 \mathrm{~kg}$ /hari (Radius 2008). Usaha budi daya stroberi ini menjanjikan untuk dikembangkan. Dalam skala nasional, produksi stroberi di Indonesia meningkat yang semula 41.035 ton pada tahun 2011 menjadi 169.796 ton pada tahun 2012 (Deptan 2014).

Penelitian ini bertujuan untuk mengidentifikasi spesies trips di pertanaman stoberi, mengamati kerapatan populasi, luas serangan, dan ukuran tubuh trips yang menyerang tanaman stroberi, serta mengamati gejala kerusakan yang ditimbulkan trips pada tanaman stoberi di Desa Alamendah, Kecamatan Rancabali, Kabupaten Bandung, Jawa Barat.

\section{BAHAN DAN METODE}

\section{Lokasi dan waktu penelitian}

Penelitian dilakukan di Desa Alamendah, Kecamatan Rancabali, Kabupaten Bandung, Jawa 
Barat. Identifikasi dan pengukuran trips dilakukan di Laboratorium Biosistematika Serangga, Departemen Proteksi Tanaman, Institut Pertanian Bogor. Penelitian dilaksanakan dari bulan Maret sampai Agustus 2012.

\section{Penentuan lahan pengamatan}

Penelitian dilakukan pada 3 lahan pertanaman stroberi yang berumur 1 sampai 1,5 tahun. Lahan pertanaman tersebut merupakan milik petani dan terletak di daerah sentra stroberi di Desa Alamendah.

\section{Pengamatan dan pengambilan sampel spesies trips di pertanaman stroberi}

Pengamatan dan pengambilan sampel untuk mengevaluasi keberadaan spesies trips pada pertanaman stroberi dilakukan dengan menepuk bunga stroberi dan ditadahi dengan nampan plastik. Pengambilan sampel trips juga dilakukan pada tanaman lain yang berada di sekitar tanaman stroberi yang berada dalam radius $10 \mathrm{~m}$ dari batas terluar lahan. Pengambilan sampel dilakukan dengan metode acak sistematis Binns \& Nyrop (1992) yang telah dimodifikasi, yaitu dengan menentukan baris pertama secara acak, kemudian baris selanjutnya ditentukan dengan interval 5 baris sampai memperoleh 5 polibag dengan jumlah 1 tanaman/polibag. Proses identifikasi dilakukan berdasarkan kunci identifikasi Mound \& Kibby (1998).

\section{Pengukuran bagian tubuh trips}

Pengukuran bagian tubuh trips dilakukan dengan terlebih dahulu membuat preparat mikroskop (berdasarkan metode Mound \& Kibby 1998) dari 90 imago trips betina. Pengukuran bagian tubuh trips dilakukan di bawah mikroskop stereo dengan bantuan mikrometer dengan parameter panjang tubuh, panjang abdomen, panjang antena, panjang sayap, lebar kepala, dan lebar toraks. Pengukuran tubuh dilakukan untuk mengumpulkan informasi dasar mengenai biologi trips $F$. intonsa pada tanaman stroberi dikarenakan belum adanya laporan sebelumnya tentang $F$. intonsa yang menyerang tanaman stroberi di Indonesia. Selain itu juga ukuran tubuh trips berpengaruh terhadap tingkat reproduksi yang dimiliki trips tersebut.

\section{Pengamatan keberadaan fase perkembangan F. intonsa}

Pengamatan mengenai keberadaan fase perkembangan trips pada bunga stroberi dilakukan dengan mengamati bunga, batang dan buah stroberi secara langsung dan meneteskan cairan acid fuchsin pada bagian bunga dan daun untuk mengetahui keberadaan telur trips di dalam jaringan bunga. Dalam pengamatan ini juga dihitung perbandingan antara imago $F$. intonsa jantan dan betina pada tanaman stroberi.

\section{Pengamatan kerapatan populasi dan luas serangan $F$. intonsa}

Penentuan kerapatan populasi trips di lahan stroberi dilakukan pada 3 lahan yang berbeda dengan mengamati 1 tanaman sampel/polibag, dengan jumlah polibag sampel 10 polibag/lahan. Pemilihan polibag sampel dilakukan secara acak sistematis dengan interval 2 baris dan mengambil 2 bunga/tanaman/polibag. Pengamatan dilakukan 4 hari sekali, karena lama mekar bunga hanya 4 hari. Pengamatan dilakukan hanya selama 3 minggu, yaitu selama periode bunga mekar sampai buah stoberi dipanen. Pengamatan ini dilakukan pada pukul 11:00 sampai 14:00 WIB karena aktivitas tertinggi trips terjadi pada waktu tersebut. Selanjutnya nilai rataan dan galat kerapatan populasi trips dihitung menggunakan perangkat lunak SPSS 18 for Windows.

\section{Pengamatan gejala kerusakan serangan $F$. intonsa}

Pengamatan gejala kerusakan akibat serangan trips dilakukan dengan cara memilih secara acak 30 sampel (10 bunga/lahan) bunga stroberi yang masih kuncup. Bunga tersebut kemudian dikurung dengan kurungan plastik berbentuk silinder berdiameter $5 \mathrm{~cm}$ dan tinggi $10 \mathrm{~cm}$. Ke dalam masing-masing kurungan dimasukkan trips sebanyak 10 individu trips dengan rasio 3 individu jantan dan 7 individu betina. Berdasarkan hasil pengamatan pendahuluan, rasio jantan berbanding betina trips di stoberi adalah $1: 3$. Trips dimasukkan ke dalam kurungan dengan cara memindahkan trips ke dalam plastik terlebih dahulu, kemudian ujung plastik dipotong dan trips akan diarahkan untuk bergerak ke dalam kurungan. Kriteria gejala kerusakan dibandingkan dengan gejala serangan 
F. occidentalis pada stroberi di daerah subtropis (Steiner 2003) dan diamati hingga buah dapat dipanen. Sebagai pembanding digunakan bunga stroberi sebanyak 10 bunga yang dikurung seperti halnya pengamatan gejala serangan, namun tanpa diinfestasikan trips. Bunga tanpa serangan trips ini disebut bunga kontrol. Data pengamatan disajikan secara deskriptif.

\section{Pengamatan luas serangan trips}

Serangan trips diukur dengan menaksir persentase serangan pada setiap tanaman sampel, dihitung menggunakan rumus:

Luas serangan trips $=\frac{\text { Jumlah tanaman terserang }}{\text { Jumlah tanaman sampel }} \times 100 \%$

\section{HASIL}

\section{Jenis spesies dan ukuran tubuh trips}

Di Desa Alamendah spesies trips yang ditemukan pada tanaman stroberi adalah spesies $F$. intonsa yang memiliki warna kepala, toraks dan abdomen cokelat kekuningan serta memiliki seta oseli III yang terletak di dalam batas segitiga oseli dan lebih panjang dari seta oseli I. Trips $F$. intonsa memiliki rata-rata panjang tubuh, antena, abdomen, dan sayap serta lebar kepala dan toraks berturut-turut adalah 1,45 $\pm 0,01 \mathrm{~mm}, 0,26 \pm$ $0,002 \mathrm{~mm}, 0,94 \pm 0,09 \mathrm{~mm}, 0,78 \pm 0,005 \mathrm{~mm}$, $0,17 \pm 0,001 \mathrm{~mm}$, dan $0,29 \pm 0,003 \mathrm{~mm}$. Trips $F$. intonsa memiliki warna tubuh yang bervariasi, kepala dan toraks berwarna cokelat keabu-abuan dengan abdomen cokelat; atau kepala, toraks, dan abdomen cokelat keabu-abuan; atau kepala, toraks, dan abdomen seluruhnya cokelat atau kekuningan. Ruas antena I dan II berwarna cokelat, ruas III kuning, ruas IV dan $\mathrm{V}$ dengan bagian basal kuning dan bagian distal cokelat, dan ruas VI-VIII cokelat. Seta oseli III terletak di dalam batas segitiga oseli dan lebih panjang dari seta oseli I. Metanotum tanpa campaniform sensilla. Ruas abdomen VIII dengan posteromarginal comb yang utuh dan microtrichia yang pendek (Gambar 1).

\section{Keberadaan fase perkembangan $F$. intonsa}

Hasil pengamatan menunjukkan bahwa seluruh fase perkembangan $F$. intonsa terdapat pada bunga stroberi. Telur $F$. intonsa terdapat di dalam jaringan kelopak bunga stroberi. Setelah diwarnai dengan acid fuchsin pada kelopak bunga stroberi terlihat bintik-bintik merah muda yang merupakan telur dari F. intonsa. Nimfa dan imago F. intonsa ditemukan bergerak bebas pada bunga stroberi. Stadia pupa tidak ditemukan pada bagian tanaman stroberi yang diamati (bunga, batang, daun, dan buah) karena trips pada umumnya menjalani stadia pupa di tanah.

\section{Kerapatan populasi dan luas serangan $\boldsymbol{F}$. intonsa}

Jumlah populasi rata-rata $F$. intonsa yang teramati dari 30 sampel tanaman berkisar antara 1,8 sampai 2,3 individu/bunga, dengan rasio perbandingan jantan dan betina sebesar $1: 3$. Luas serangan $F$. intonsa pada ketiga lahan menunjukkan

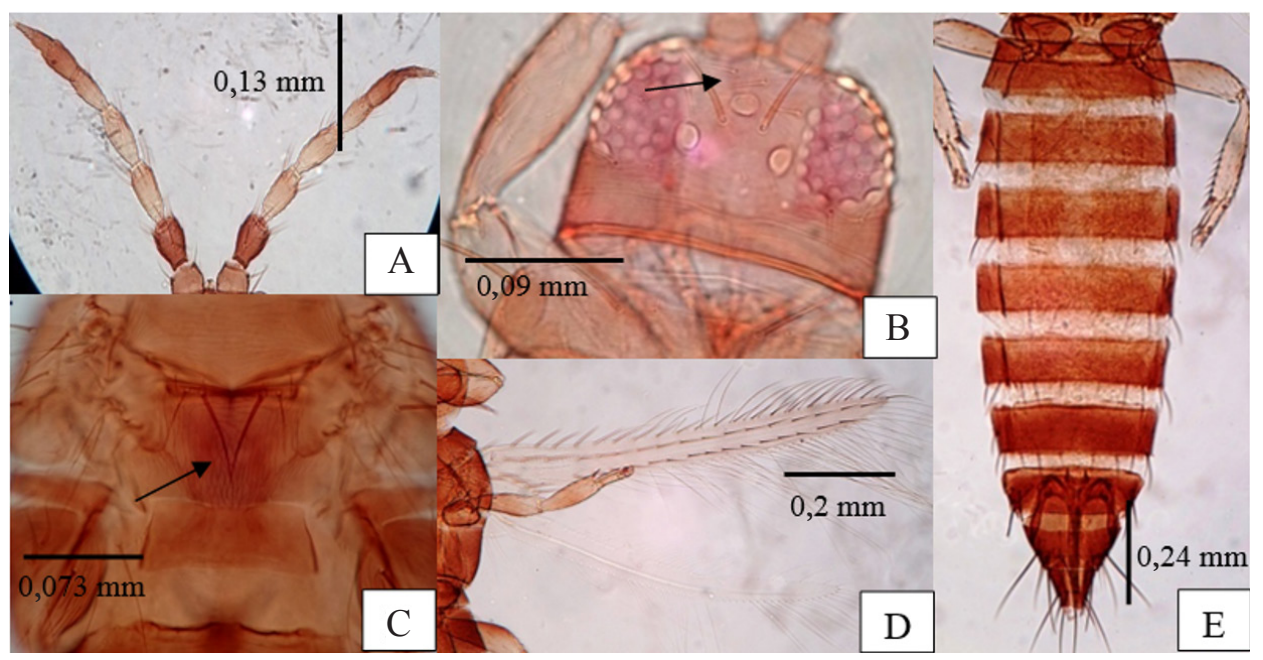

Gambar 1. Bagian tubuh Frankliniella intonsa. A: antena 8 ruas; B: kepala dengan seta oseli 1 (tanda panah); $\mathrm{C}$ : toraks (metanotum) tanpa campaniform sensilla (tanda panah); D: sayap; E: abdomen 11 ruas. 
angka yang cukup tinggi, yaitu berkisar antara $68,4 \%$ sampai $82,2 \%$. Trips $F$. intonsa menyerang bunga stroberi secara merata pada lahan I, lahan II, dan lahan III (Tabel 1). Selama 6 kali pengamatan di lahan pertanaman stroberi, jumlah populasi $F$. intonsa cenderung menurun (Gambar 2).

\section{Perkembangan gejala serangan $\boldsymbol{F}$. intonsa}

Perkembangan gejala serangan $F$. intonsa pada bunga stroberi dimulai pada 1 hari setelah infestasi (HSI), yaitu terlihat bercak cokelat pada mahkota bunga. Bercak tersebut muncul pada sebagian pangkal mahkota dan bertambah sehingga seluruh pangkal mahkota lainnya menjadi berwarna cokelat (Gambar 3A). Pada 2 HSI mulai terlihat munculnya gejala bercak cokelat pada tangkai sari dan pada 4 HSI gejala pangkal kelopak mencokelat mulai terlihat (Gambar 3B).

Setelah 4 HSI sebagian besar mahkota bunga sampel telah rontok. Pada mahkota bunga kontrol tidak dijumpai bercak cokelat pada semua bagian yang diamati, namun seluruh mahkota bunga kontrol rontok pada 3 HSI sampai 4 HSI. Tanaman

Tabel 1. Rataan kerapatan populasi dan luas serangan trips Frankliniella intonsa Kecamatan Rancabali

\begin{tabular}{lcc}
\hline Lokasi $^{\text {a }}$ & $\begin{array}{c}\text { Kerapatan populasi } \\
\text { (individu/bunga) } \\
\text { (rataan } \pm \mathrm{SE})\end{array}$ & $\begin{array}{c}\text { Luas serangan } \\
(\%) \\
\text { (rataan } \pm \mathrm{SE})\end{array}$ \\
\hline Lahan 1 & $1,8 \pm 0,3$ & $68,4 \pm 5,8$ \\
Lahan 2 & $2,3 \pm 0,3$ & $82,2 \pm 2,9$ \\
Lahan 3 & $2,1 \pm 0,4$ & $81,1 \pm 2,2$ \\
\hline
\end{tabular}

a Jumlah bunga sampel 20 untuk masing-masing lahan. stroberi melakukan penyerbukan sendiri pada umur bunga 2 sampai 4 hari. Setelah umur 4 hari dasar bunga akan membesar dan membentuk buah semu (pseudocarp), buah sebenarnya adalah achene yang sering disebut biji (istilah biji berdasarkan Rukmana 1999). Dengan demikian, sampai dengan 4 HSI baik pada bunga yang diserang trips maupun kontrol mengalami perontokan mahkota di waktu yang sama. Namun, pada bunga yang diinfestasi trips mahkota bunga yang rontok menunjukkan adanya gejala kerusakan.

Bagian benang sari yang terdapat gejala bercak cokelat adalah tangkai sari. Bercak cokelat tersebut merupakan akibat dari aktivitas makan $F$. intonsa yang memiliki tipe mulut meraut-mengisap. Pada bunga kontrol tidak dijumpai bercak cokelat pada benang sari.

Kelopak bunga merupakan salah satu bagian bunga yang diserang oleh $F$. intonsa. Bagian kelopak yang diserang adalah bagian pangkal kelopak bunga dengan gejala berupa adanya bercak cokelat (Gambar 3C), sama seperti gejala yang timbul pada bagian tangkai sari. Berbeda dengan bunga stroberi sampel, pada pangkal kelopak bunga kontrol tidak ditemukan adanya gejala bercak cokelat.

Pada beberapa buah sampel ditemukan gejala burik pada buah stroberi yang masih hijau (Gambar 3D). Gejala ini diakibatkan oleh aktivitas makan F. intonsa pada buah stroberi muda sehingga saat buahnya membesar timbul gejala burik. Malformasi yang terjadi sebagian besar berada di ujung buah stroberi. Setelah bunga berkembang menjadi buah, bagian ujung buah menjadi tidak

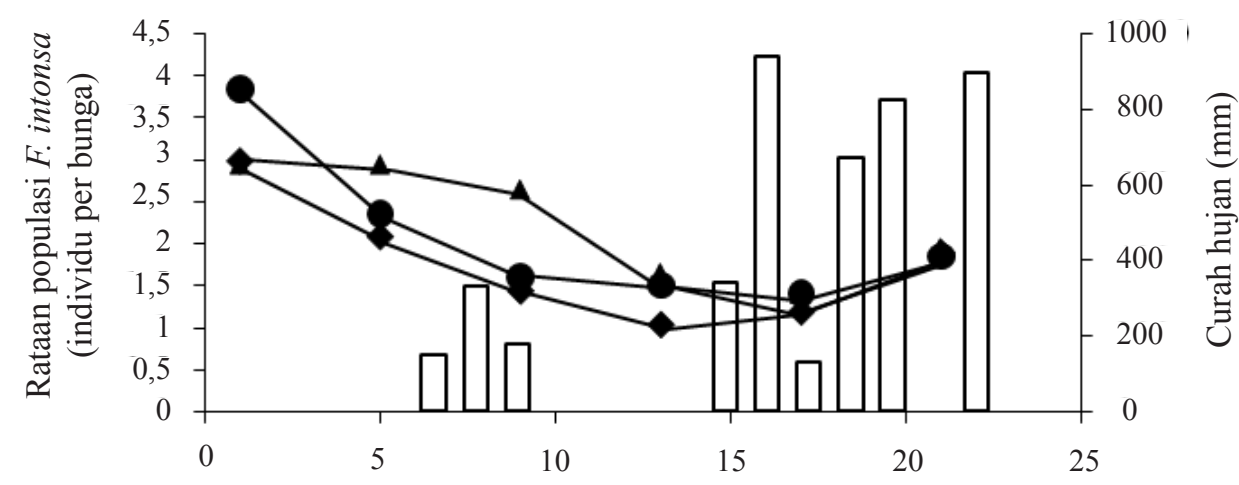

Tanggal

Gambar 2. Rataan kerapatan populasi Frankliniella intonsa selama 3 minggu dan curah hujan Kecamatan Rancabali bulan Mei 2012. $\rightarrow$ : populasi lahan III. 
berkembang sempurna dan terjadilah malformasi. Malformasi buah yang parah mengakibatkan roset pada buah dan ukuran buah menjadi kecil.

Hasil panen menunjukkan bahwa serangan F. intonsa dapat menyebabkan malformasi pada buah stroberi. Sebanyak 13 dari 30 buah sampel yang dipanen $(43,3 \%)$ buah sampel mengalami malformasi pada bagian ujung buah (Gambar 3E1). Kejadian biji stroberi hitam (Gambar 3E2) lebih banyak yakni 22 dari 30 buah sampel (73,3\%). Gejala lain adalah tekstur kulit buah yang keriput (Gambar 3G), yang muncul pada buah yang sebelumnya mengalami gejala burik di sekitar biji stroberi. Dengan demikian bila tekstur buah panen keriput maka gejala tersebut merupakan tingkat lanjut dari gejala burik yang terjadi pada buah stroberi muda. Buah kontrol memiliki bentuk yang sempurna dan biji yang kekuningan (Gambar 3H).

\section{Trips di sekitar lahan stroberi}

Trips yang ditemukan pada tanaman yang berada di sekitar tanaman stoberi adalah Thrips palmi (Karny) (Gambar 4A) dan Microcephalothrips abdominalis (Crawford) (Gambar 4B) (Tabel 2). Selain pada tanaman bawang daun, tomat, kentang, dan blackberry, T. palmi juga ditemukan pada gulma Amaranthus sp. Selain itu, terdapat juga trips $M$. abdominalis yang ditemukan pada gulma babadotan (Ageratum haustonianum) dan tanaman tomat.
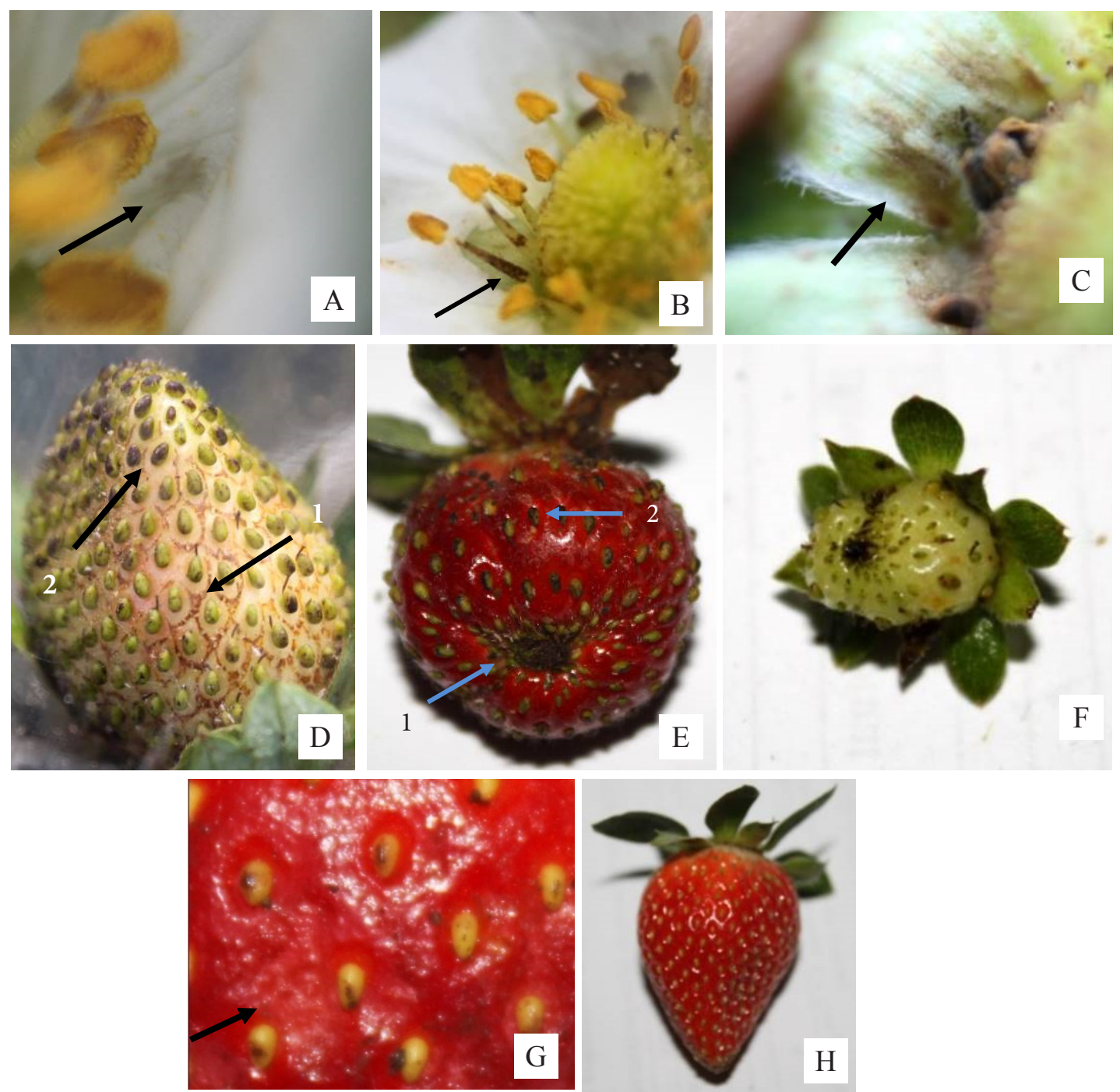

Gambar 3. Gejala serangan Frankliniella intonsa pada bunga dan buah stroberi. A: bercak cokelat pada mahkota bunga stroberi; B: bercak cokelat pada tangkai sari; C: bercak cokelat pada pangkal kelopak bunga; D: burik disekitar biji pada buah muda (1) dan biji stroberi muda hitam (2); E: malformasi yang terjadi pada ujung buah yang dipanen (1) dan biji yang menghitam (2); F: 1 dari 30 buah sampel yang terlambat matang; G: permukaan kulit buah stroberi yang keriput, buah tersebut juga mengalami roset dan burik disekitar biji; H: buah kontrol. 


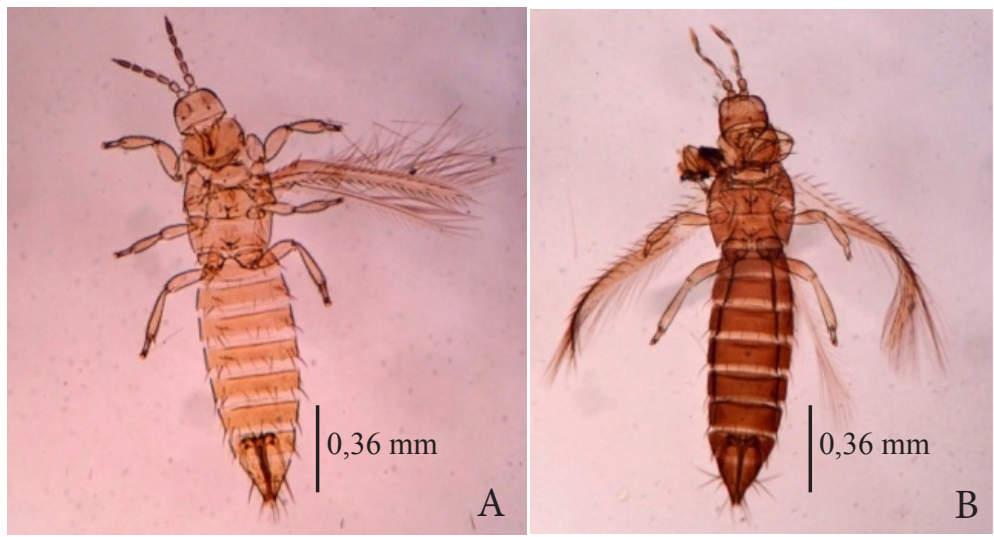

Gambar 4. Thrips palmi dalam awetan preparat mikroskop (A) dan Microcephalothrips abdominalis dalam awetan preparat mikroskop (B).

Tabel 2. Keanekaragaman trips pada tanaman di sekitar tanaman stroberi

\begin{tabular}{lccccccc}
\hline \multirow{2}{*}{ Spesies trips } & \multicolumn{7}{c}{ Tanaman inang } \\
\cline { 2 - 7 } & Stroberi & B. daun & Tomat & Kentang & Blackberry & Babadotan & Amaranthus sp. \\
\hline Frankliniella intonsa & $\sqrt{ }$ & $\sqrt{ }$ & - & - & - & - & - \\
Thrips palmi & - & $\sqrt{ }$ & $\sqrt{ }$ & $\sqrt{ }$ & $\sqrt{ }$ & - & $\sqrt{ }$ \\
$\begin{array}{l}\text { Microcephalothrips } \\
\text { abdominalis }\end{array}$ & - & - & $\sqrt{ }$ & - & - & $\sqrt{ }$ & - \\
\hline V. & & & & & & &
\end{tabular}

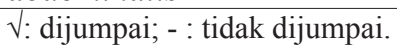

\section{PEMBAHASAN}

Spesies trips $F$. intonsa pertama kali dilaporkan di Indonesia tahun 2008 pada tanaman wortel dan sawi (Azzahroh 2008), tetapi tidak menyebutkan stroberi sebagai inang $F$. intonsa. Laporan ini merupakan laporan pertama tentang $F$. intonsa pada tanaman stroberi di daerah Ciwidey.

Trips $F$. intonsa dikenal juga dengan sebutan flower thrips dan merupakan spesies trips yang menetap di bunga dan menginfestasi berbagai jenis bunga dari berbagai ordo dan spesies tumbuhan (Murai 1988; Atakan \& Ozgur 2001). Spesies ini merupakan kerabat dekat dari $F$. occidentalis. Kedua spesies trips ini mirip dan terkadang sulit dibedakan walaupun pengamatan menggunakan mikroskop cahaya (Wang et al. 2010). Menurut Parker et al. (2004), F. occidentalis menyebabkan kerusakan yang parah pada tanaman stroberi di negara subtropis. Tanaman inang lain $F$. intonsa adalah Cucurbitaceae, kacang-kacangan, selada, bawang merah, jagung, dan tanaman hias. Daerah persebaran trips ini di Asia meliputi Bangladesh, Pakistan, Turki, India, Cina, Mongolia, Jepang, Korea, Taiwan, Thailand, Malaysia, Filipina, dan Indonesia (Wang et al. 2010).
Pada tanaman stroberi selama penelitian $F$. intonsa merupakan satu-satunya spesies trips yang ditemukan. Dengan demikian dapat disimpulkan bahwa tanaman stroberi merupakan inang utama bagi $F$. intonsa pada lahan tersebut. Ukuran tubuh F. intonsa yang ditemukan lebih pendek dari ukuran tubuh $F$. occidentalis yang berkisar dari $1,54 \mathrm{~mm}$ sampai $1,65 \mathrm{~mm}$. Namun ukuran tubuh F. intonsa lebih panjang dibandingkan dengan ukuran tubuh Frankliniella fusca (Hinds) yang memiliki ukuran tubuh 1,13 mm sampai 1,21 mm (De Kogel et al. 1999). Jika dihubungkan dengan hasil penelitian De Kogel et al. (1999) hal ini berarti tingkat reproduksi $F$. intonsa lebih rendah dibandingkan dengan $F$. fusca.

Kerapatan populasi $F$. intonsa di lahan stroberi diamati pada pukul 11:00 sampai pukul 14:00 WIB, hal ini berdasarkan karena menurut Atakan \& Ozgur (2001) trips F. intonsa merupakan spesies serangga diurnal yang aktif mulai pukul 06:00 sampai pukul 16:00 dengan tingkat aktivitas paling tinggi diantara pukul 11:00 sampai pukul 14:00. Atakan (2011) menyebutkan bahwa tahun 2008 kepadatan populasi F. occidentalis pada lahan stroberi di Turki sebesar 10,2 individu/ bunga. Hal ini mengindikasikan bahwa populasi 
trips pada tanaman stroberi di Indonesia jauh lebih rendah dibandingkan dengan populasi trips pada stroberi di Turki dan dapat mempengaruhi perbedaan status hama trips pada tanaman stroberi di Turki dan di Indonesia. Kerapatan populasi trips selama pengamatan ke-2 hingga pengamatan ke-5 cenderung menurun, hal ini diduga diakibatkan curah hujan yang tinggi. Populasi trips meningkat kembali pada pengamatan ke-6 karena hujan mulai berhenti turun. Trips memiliki ukuran tubuh yang sangat kecil, sehingga sangat mudah terpengaruh oleh keadaan cuaca seperti turunnya hujan.

Luas serangan $F$. intonsa di lapangan dihitung berdasarkan keberadaan $F$. intonsa dan gejala serangannya pada bunga stroberi. Individu tanaman yang diamati untuk menghitung luas serangan $F$. intonsa sama dengan tanaman yang digunakan dalam pengamatan tingkat kerapatan populasi $F$. intonsa.

Tingginya tingkat populasi $F$. intonsa di lapangan akan mengakibatkan tingginya luas serangan yang terjadi yang disebabkan oleh $F$. intonsa. Tingginya luas serangan $F$. intonsa di lahan stroberi berpengaruh terhadap kualitas buah stroberi yang dihasilkan. Atakan (2011) juga menyebutkan bahwa trips $F$. occidentalis yang menyerang tanaman stroberi di Turki tidak dinyatakan sebagai hama yang penting secara ekonomi walaupun populasinya mencapai 24 individu imago/bunga dan 2 individu nimfa/bunga. Namun kualitas buah stroberi yang dihasilkan mengalami penurunan. Trips $F$. intonsa pada tanaman stroberi di Indonesia belum termasuk ke dalam hama penting dalam segi penurunan kuantitas, namun hama trips merupakan hama yang menurunkan kualitas dan kosmetik buah stroberi yang dihasilkan. Selain itu, trips berpotensi menjadi hama penting jika populasinya terus meningkat dan diiringi dengan kondisi cuaca yang mendukung.

Perkembangan gejala serangan trips pada bunga stroberi dimulai dari umur bunga 1 HSI dan bagian bunga yang pertama kali diserang adalah mahkota bunga. Serangan trips berupa bercak kecokelatan pada bagian-bagian bunga seperti mahkota, kelopak, benang sari, dan putik. Hal ini sesuai dengan yang diamati Steiner (2003) pada stroberi yang diserang $F$. occidentalis, yaitu pada awal serangan mahkota bunga berwarna cokelat.
Serangan trips juga terjadi pada buah stroberi muda dan mengakibatkan kulit buah stroberi menjadi burik. Selain itu, biji stroberi berubah warna menjadi cokelat yang merupakan gejala serangan trips pada buah stroberi muda. Steiner (2003) juga menyebutkan bahwa serangan $F$. occidentalis pada buah muda akan mengakibatkan gejala burik pada buah stroberi muda. Gejala burik ini biasanya diiringi dengan gejala hitamnya biji stroberi. Buah stroberi yang terserang trips akan mengalami malformasi pada bagian ujung buah. Hal ini menurut Parker et al. (2004) disebabkan karena aktivitas makan trips yang lebih menyukai putik bagian atas. Setelah bunga berkembang menjadi buah, bagian ujung buah menjadi tidak berkembang sempurna dan terjadilah malformasi. Malformasi buah yang parah mengakibatkan roset pada buah dan ukuran buah menjadi kecil.

Satu dari 30 buah sampel yang dipanen terdapat 1 buah yang hingga hari ke-21 belum menampakkan tanda-tanda kematangan dan disertai gejala buah roset dan burik di sekitar biji. Belum diketahui penyebab keterlambatan kematangan buah stroberi ini, namun gejala buah roset dan burik di sekitar biji sama dengan gejala serangan F. intonsa.

Bawang daun merupakan salah satu inang dari $F$. intonsa, namun dalam penelitian ini $F$. intonsa diketahui bahwa tanaman stroberi lebih disukai dari pada tanaman inang utamanya. Hal ini disebabkan karena bawang daun ditanam secara tumpang sari dengan stroberi, sehingga tidak menutup kemungkinan $F$. intonsa dari stroberi berpindah ke bawang daun. Namun, bawang daun tidak dijadikan tempat berkembangbiak oleh $F$. intonsa, yang didukung oleh tidak ditemukannya telur $F$. intonsa pada dalam jaringan daun bawang daun saat dilakukan pewarnaan dengan acid fuchsin.

Trips lain yang ditemukan disekitar pertanaman stroberi adalah T. palmi. T. palmi dikenal juga dengan nama melon thrips adalah trips yang bersifat polifag dengan persebaran hampir di seluruh dunia, spesies ini berasal dari Asia Tenggara dan ditemukan di daerah beriklim tropik basah (Moritz et al. 2004). Hama T. palmi adalah hama penting pada kurang lebih 20 famili terutama adalah Cucurbitaceae dan Solanaceae (Moritz et al. 2004) 
Pada gulma babadotan ditemukan trips $M$. abdominalis. Trips M. abdominalis merupakan satu-satunya anggota genus Microcephalothrips. Genus ini merupakan kerabat dekat genus Thrips. Tumbuhan genus Ageratum merupakan salah satu inang dari $M$. abdominalis. Trips $M$. abdominalis juga berperan sebagai penyerbuk bagi tumbuhan genus Ageratum. Serangga ini juga menyerang berbagai tanaman hias dari famili Asteraceae. Selain pada gulma A. haustonianum, M. abdominalis juga ditemukan pada tanaman tomat Di Asia dilaporkan bahwa M. abdominalis juga menyerang tanaman hias famili Orchidaceae, tanaman teh, dan padi (Greber et al. 1991).

\section{KESIMPULAN}

Trips yang menyerang tanaman stroberi di Desa Alamendah, Kecamatan Rancabali, Kabupaten Bandung adalah spesies $F$. intonsa. Trips $F$. intonsa memiliki ukuran tubuh lebih dari $1 \mathrm{~mm}$ dan dapat terlihat dengan mata telanjang pada bunga stroberi. Dalam satu bunga stroberi terdapat 2 sampai 3 individu trips $F$. intonsa, namun jumlahnya dapat meningkat jika populasinya tinggi. Luas serangan F. intonsa di lahan stroberi yang diamati mencapai $82,2 \%$ dengan serangan hanya terdapat pada bunga dan buah stroberi muda. Serangan trips ini, dapat menyebabkan buah stroberi yang dipanen mengalami malformasi dengan tingkat kejadian sebesar $43,33 \%$. Buah stroberi muda yang terserang memiliki tekstur kulit buah yang keriput pada saat dipanen dan akan menurunkan nilai jual buah stroberi yang dihasilkan.

\section{DAFTAR PUSTAKA}

[Balijestro] Balai Penelitian Tanaman Jeruk dan Buah Subtropika. 2014. Identifikasi hama dan penyakit tanaman stroberi. Tersedia pada: http:// balitjestro.litbang.pertanian.go.id/id/identifikasihama-dan-penyakit-stroberi-(fragaria- $\% \mathrm{C} 3 \% 97$ ananassa).html [diakses pada 15 April 2015].

[Deptan] Departemen Pertanian Indonesia. 2014. Basis data statistik pertanian hortikultura. Tersedia pada: http://aplikasi.pertanian.go.id/ bdsp/hasil_kom.asp [diakses pada 15 April 2015].
Atakan EA, Ozgur AF. 2001. Determining the favorable sampling time for Frankliniella intonsa on cotton. Di dalam: Marullo R et al., (Eds.) Proceedings of the 7th International Symposium on Thysanoptera (Canbera, 2-7 Juli 2001). pp. 225-227. Canberra: CSIRO Publishing.

Atakan E. 2011. Population densities and distributions of the western flower thrips (Thysanoptera: Thripidae) and its predatory bug, Orius niger (Hemiptera: Anthocoridae), in strawberry. International Journal Agriculture Biology 13:638-644.

Azzahroh AS. 2008. Keanekaragaman Spesies Trips (Ordo: Thysanoptera) pada Tanaman Sayuran dan Buah-buahan di Kabupaten Bogor dan Cianjur. Skripsi. Bogor: Institut Pertanian Bogor.

Binns MR, Nyrop JP. 1992. Sampling insect populations for the purpose for IPM decision making. Annual Review of Entomology 37:427-53.

De Kogel WJ, Bosco D, van der Hoek M, Mollema C. 1999. Effect of host plant on body size of Frankliniella occidentalis (Thysanoptera: Thripidae) and its correlation with reproductive capacity. European Journal of Entomology 96: 365-368.

Greber RS, Klose MJ, Teakle DS, Milne JR. 1991. High incidence of Tobacco streak virus in tobacco and its transmission by Microcephalothrips abdominalis and pollen from Ageratum houstonianum. Plant Disease 75:450-452. doi: http://dx.doi.org/10.1094/PD-75-0450.

Moritz G, Mound LA, Morris DC, Goldarazena A. 2004. Pest thrips of the world [CD-ROM]. Canberra: CSIRO Publishing. 1 CD-ROM.

Mound LA, Kibby G. 1998. Thysanoptera An Identification Guide. $2^{\text {nd }}$ Edition. Canberra: CSIRO Entomology.

Murai T. 1998. Studies on the ecology and control of flower thrips, Frankliniella intonsa (Trybom). Bulletin of the Shimane Agricultural Experiment Station 23:1-73.

Parker D, Agent S, Cherokee, Counties S. 2004. Western flower thrips in strawberries. South Carolina (US): Clemson University. Available at: http://www.clemson.edu/ipm/reports/03parkerb. pdf. [accessed 2012 Jan 19].

Radius DB. 2008. Kebun stroberi 'Ngalingkung' Bandung. Jakarta: Kompas. Rubrik Nasional. Tersedia pada: http://nasional.kompas.com/read/ 2008/05/10/10015616/kebun.stroberi. ngalingkung.bandung. [diakses 20 Mei 2010].

Rukmana R. 1999. Stroberi Budi Daya dan Pascapanen. Yogyakarta: Kanisius. 
Steiner M. 2003. Which Thrips Is That? A Guide to the Key Species Damaging in Strawberry. Australia: NWS Agriculture.

Wang CL, Lin FC, Chiu YC, Shih HT. 2010. Species of Frankliniella Trybom (Thysanoptera: Thripidae) from the Asian-Pasific Area. Zoological Studies 49:824-838.
Zamora JEG, Mari FG. 2003. The efficiency of saveral sampling methods for Frankliniella occidentalis (Thysanoptera: Thripidae) in strawberry flowers. Journal of Applied Entomology 127:516-521. doi: http://dx.doi.org/10.1046/j.0931-2048.2003. 00783.x. 